\author{
Research Article
}

\title{
A COMPARATIVE CLINICAL STUDY TO EVALUATE THE EFFICACY OF GUDUCHYADI KASHAYA AND RAJRUKSHADIPACHANA KASHAYA IN THE MANAGEMENT OF EKA KUSHTA W.S.R TO PSORIASIS
}

\section{Moulika Markonda1*, Sowmya S.B ${ }^{2}$}

${ }^{*}$ PG Scholar, ${ }^{2}$ Professor \& HOD, Dept of Kayachikitsa, Ramakrishna Ayurvedic Medical College Hospital \& Research Centre, Bengaluru, India.

\section{Article info \\ Article History: \\ Received: 27-09-2021 \\ Revised : 10-10-2021 \\ Accepted: 20-10-2021 \\ Published: 07-11-2021}

\section{KEYWORDS:}

Eka kustha, Psoriasis, Skin, Skin diseases, Guduchyadi kashayam, Rajvrukashadipa chana kashaya.

\begin{abstract}
In Ayurveda, all skin diseases have been described under the umbrella of Kushtha. Ekakusta is considered as the most commonest skin disease that can affect an individual. Acharya Charak has described the involvement of Vata-Kapha in Eka Kushtha. In the present study Eka kushtha is compared with psoriasis due to resemblance of signs symptoms and causative factors with it. Psoriasis is a papulosquamous disorder of the skin, characterized by sharply defined erythematosquamous lesions this illness exhibits a prompt response if treated carefully, left it may run a very chronic course extending into larger area of the body.

Ayurveda focuses more on curative management than palliative management. The drug used in the treatment of Ayurveda does not have complications like modern treatment. Repeated Sodhana prevent the recurrence of the disease. Similarly various preparations have been advocated for the management of Psoriasis.

The drugs used in this study are Guduchyadi Kashaya \& Rajrukshadi Pachana Kashaya. Both the Kashayas are said to be effective in skin diseases. As per Yogaratnakara, Guduchyadhi Kwath has been mentioned as one of the drug having curative effect on all types of Kustha. Hence for present study the orally Guduchyadi Kwath is taken for EkaKustha treatment. The drugs in Guduchyadi Kwatha are Kusthaghana, Twachya, Swedal, Tridosh shamaka, as well as with Rasayan properties, which is beneficial to break down the pathogenesis of disease. As per Gadanigraha, as mentioned in Kayachikitsakhanda, Rajvrukshadipachana Kashaya is mentioned for the treatment of Ekakushtha. Ingredients in Rajvrukshadi Pachana Kashaya reduce Kapha dosha and most of them act on the skin. Kwatha dravyas are Rasadushtihara, Kaphapittahara, Deepana, Twachya, and also having antibacterial, antimicrobial, antiparasitic and anti-inflammatory properties, Hence, it is helpful for clearing the skin infections.
\end{abstract}

\section{INTRODUCTION}

Skin is considered the mirror of the body and is also the largest organ of the body [1]. The primary function of skin is the protection of organs but beside this, it has many other functions, such as it preserves glow of body as well as face, it resists bacteria, toxins and ultraviolet rays. According to modern science psoriasis is chronic inflammatory disease noninfectious disease of skin which is characterized by well-defined erythematous plaque with silvery scale ${ }^{[2]}$.

\begin{tabular}{|l|l|}
\hline \multicolumn{3}{c|}{ Access this article online } \\
\hline Quick Response Code & \begin{tabular}{l} 
https://doi.org/10.47070/ijapr.v9iSuppl1.2090 \\
\hline
\end{tabular} \\
\hline
\end{tabular}

According to Ayurveda, skin is one of the five Gyanendriya which is responsible for touch sensation. Ayurveda has mentioned about Twak (skin) to be Upadhatu of Rasa Dhatu and has been categorized in seven layers taking in account the different types of skin disease involvement in different layers of skin[5]. In Ayurveda, all the skin diseases has been described under the heading of Kustha. Many of the Ayurvedic text like Charaka, Sushruta and Vagbhata have explained Kustha as one of the Mahagadh. Understanding of common people for the word Kustha is merely leprosy, but according to Ayurveda the, Kustha is considered as skin disorder as well as leprosy[8]. There are total 18 types of Kustha. Further Kustha is classified into seven MahaKustha and eleven Kshudra Kustha. Acharyas have described all the Kustha as Tridoshic but type of Kustha depends on the predominance of particular Dosha ${ }^{[9]}$. Acharya Charaka 
has described the involvement of Vata-Kaphaj Doshaja in Eka-Kustha. Eka Kustha can be co-related with psoriasis as the symptoms of Eka Kustha is described in classical text they are very much identical with that of Psoriasis. For example, Krushna aruna Varna as Erythema, Mastyashakalopam as Scaling, Mahavastu as Degree of involvement etc.

\section{Aims and Objectives}

To study the efficacy of Guduchyadi Kashaya and Rajvrukashadipachana Kashaya in EkaKustha w.s.r to Psoriasis.

\section{Objectives}

- To evaluate the clinical efficacy of Guduchyadi kashaya.

- To evaluate the clinical efficacy of Rajvrukshadi pachana kashaya.

- To compare the effect of Guduchyadikashaya and RajvrukshadipachanaKashaya

MATERIALS AND METHODS

Group A: Guduchyadi Kashaya [6]

\begin{tabular}{|l|l|}
\hline Dose & 2 Pala $(80 \mathrm{ml})$ into two divided dose of 40ml each \\
\hline Aushadisevankala & Abhukta kala (morning and evening) \\
\hline Anupana & Ushnodaka \\
\hline Duration & 30days \\
\hline Follow up & 10th, 20th, 30th day \\
\hline
\end{tabular}

\section{Group B: Rajvrukashadipachana Kashaya [7]}

Kashaya is purchased from Kotakkal Ayurveda

\begin{tabular}{|l|l|}
\hline Dose & 2 Pala $(80 \mathrm{ml})$ into two divided dose of $40 \mathrm{ml}$ each \\
\hline Aushadisevankala & Abhukta kala (morning and evening) \\
\hline Duration & 30days \\
\hline Follow up & 10th, 20th, 30th day \\
\hline
\end{tabular}

\section{Criteria for Selection of Patient}

\section{Diagnostic Criteria}

Diagnosis was made on the basis of classical signs and symptoms of EkaKushtha.

\section{Inclusion Criteria}

a. Patients showing signs and symptoms of EkaKushtha.

b. Patients between age groups of 16yrs to 60yrs of age.

c. Patients belonging to both the genders.

d. No previous treatment with steroids, antimycotic, antifungal, antibacterial medication for current psoriatic lesion.

e. Subjects having ability and willingness to sign a written inform consent.

\section{Exclusion Criteria}
a. Patients having age below 16yrs and above 60yrs of age.
b. Patients with severe systemic diseases.
c. Patients who are pregnant and lactating.
d. Patients who are suffering with other skin diseases.

\section{Assessment criteria}

Subjective parameters
The raw materials of Guduchyadi Kwatha and Rajvrukshadipachana Kashaya will be of good in quality as well as the collected sources will be genuine and authentic and also Laboratory standardization will be done.

\section{Preparation of drug}

According to Sharangdhara the Guduchyadi kashaya and Rajvrukshadipachana Kashaya was prepared as per Kashaya vidhi, mentioned in our classics under all aseptic precautions in the Rasashala of our college.

50 Patients suffering from Ekakushtha were randomly selected from the OPD and IPD of Kayachikitsa from RAMCH fulfilling the inclusion criteria and fully informed consent taken.

They were randomly assigned in two groups of 25 patients. 


\section{Krushnaarunavarna (Erythema)}

PASI Scale (psoriasis area and severity index)

\begin{tabular}{|c|l|l|}
\hline Sr.No & Criteria & Score \\
\hline 1 & None & 0 \\
\hline 2 & Light red & 1 \\
\hline 3 & Red but not deep red & 2 \\
\hline 4 & Deep red & 3 \\
\hline 5 & Blackish /dark brown red & 4 \\
\hline
\end{tabular}

Mahaavastu (Degree of Involvement)

\begin{tabular}{|c|l|l|}
\hline Sr.No & Criteria & Score \\
\hline 1 & None $(0 \%-20 \%)$ & 0 \\
\hline 2 & Head $(20 \%-40 \%)$ & 1 \\
\hline 3 & Arms $(40 \%-60 \%)$ & 2 \\
\hline 4 & Trunk $(60 \%-80 \%)$ & 3 \\
\hline 5 & Legs $(80-100 \%)$ & 4 \\
\hline
\end{tabular}

Objective Parameter

Matsyashakalakopam (Scaling)

\begin{tabular}{|c|l|l|}
\hline Sr.No & Criteria & Score \\
\hline 1 & None & 0 \\
\hline 2 & Scaling is visible by scratching skin & 1 \\
\hline 3 & Moderate powdering with small lifting scales & 2 \\
\hline 4 & Heavy powdering with cracking \& lifting scales & 3 \\
\hline 5 & Heavy cracking \& lifting scales, scaling falls without rubbing & 4 \\
\hline
\end{tabular}

Thickness of the Lesion

\begin{tabular}{|l|l|l|}
\hline Sr.No & Criteria & Score \\
\hline 1 & None & 0 \\
\hline 2 & Barely palpable elevation (0.1 to $2.34 \mathrm{~mm})$ & 1 \\
\hline 3 & Slight elevation (2.35 to $3.35 \mathrm{~mm})$ & 2 \\
\hline 4 & Moderate elevation (3.36 to $4.36 \mathrm{~mm})$ & 3 \\
\hline 5 & Marked ridge (4.37mm above) & 4 \\
\hline
\end{tabular}

OBSERVATION

\begin{tabular}{|c|l|l|l|l|l|}
\hline Sr.no & Signs \& Symptoms & $\mathbf{0}$ day & $\mathbf{1 0}^{\text {th }}$ day & $\mathbf{2 0}^{\text {th }}$ day & $\mathbf{3 0}^{\text {th }}$ day \\
\hline 1. & Aswedanam & & & & \\
\hline 2. & Krushnaarunavarna & & & & \\
\hline 3. & Matsyashaklopam & & & & \\
\hline 4. & Mahaavasthu & & & & \\
\hline 5. & Thickness of the lesion & & & & \\
\hline
\end{tabular}

PASI Score

\begin{tabular}{|l|l|l|l|}
\hline Score & Mild & Moderate & Severe \\
\hline Pasi & $<10$ & $10-20$ & $>20$ \\
\hline
\end{tabular}

Overall Assessment Criteria

\begin{tabular}{|l|l|}
\hline Poor improvement & $0-25 \%$ Relief in sign and symptoms \\
\hline Mild improvement & $26-50 \%$ Relief in sign and symptoms \\
\hline Moderate improvement & $51-75 \%$ Relief in sign and symptoms \\
\hline Marked improvement & $76-100 \%$ Relief in sign and symptoms \\
\hline
\end{tabular}




\section{Study Design}

Comparative clinical study: Parallel design

Statistical Analysis

All the data which is collected is compiled and entered in a Microsoft Excel worksheet. Descriptive statistics like Mean, Median, Mode, SD, IQR, Percentages were calculated. The data were checked for suitability of statistical test and non-parametric tests are applied. For comparison between the groups the two tests used are Mann-Whitney U-test and comparison before and after the intervention Wilcoxon signed rank test is used. $p$-value of $<0.05$ is considered to be statistically significant. The data will then be analysed using Statistical software's SPSS 20

\section{Observations and Results}

Table 1: Descriptive statistics of Lakshanas of Ekakusta in Group A

\begin{tabular}{|c|c|c|c|c|c|c|c|c|c|c|}
\hline $\begin{array}{l}\text { Lakshanas of } \\
\text { Ekakusta - Group - A }\end{array}$ & At & $\mathbf{N}$ & Min & Max & Mean & SD & Median & Q1 & Q3 & Mode \\
\hline \multirow{2}{*}{ Aswedana } & Before & 25 & 2 & 4 & 3.16 & 0.69 & 3 & 3 & 4 & 3 \\
\hline & After & 25 & 0 & 2 & 0.88 & 0.67 & 1 & 0 & 1 & 1 \\
\hline \multirow{2}{*}{ Mahavasthu } & Before & 25 & 2 & 4 & 2.76 & 0.78 & 3 & 2 & 3 & 2 \\
\hline & After & 25 & 0 & 3 & 1.08 & 0.70 & 1 & 1 & 1 & 1 \\
\hline \multirow{2}{*}{ Mandala } & Before & 25 & 2 & 4 & 2.96 & 0.73 & 3 & 2 & 3.5 & 3 \\
\hline & After & 25 & 0 & 2 & 0.96 & 0.73 & 1 & 0 & 2 & 1 \\
\hline \multirow{2}{*}{ Mastyasakalopamam } & Before & 25 & 2 & 4 & 3.52 & 0.65 & 4 & 3 & 4 & 4 \\
\hline & After & 25 & 0 & 3 & 1.04 & 0.79 & 1 & 0.5 & 1.5 & 1 \\
\hline \multirow{2}{*}{ Bahalatha } & Before & 25 & 2 & 4 & 2.96 & 0.68 & 3 & 2.5 & 3 & 3 \\
\hline & After & 25 & 0 & 3 & 1.32 & 0.69 & 1 & 1 & 2 & 1 \\
\hline \multirow{2}{*}{ Rukshatha } & Before & 25 & 3 & 4 & 3.44 & 0.51 & 3 & 3 & 4 & 3 \\
\hline & After & 25 & 0 & 2 & 0.60 & 0.65 & 1 & 0 & 1 & 0 \\
\hline \multirow{2}{*}{ Unnathi } & Before & 25 & 2 & 4 & 2.60 & 0.58 & 3 & 2 & 3 & 3 \\
\hline & After & 25 & 0 & 2 & 0.88 & 0.53 & 1 & 1 & 1 & 1 \\
\hline \multirow{2}{*}{ Kandu } & Before & 25 & 2 & 4 & 3.20 & 0.71 & 3 & 3 & 4 & 3 \\
\hline & After & 25 & 0 & 2 & 0.80 & 0.65 & 1 & 0 & 1 & 1 \\
\hline \multirow{2}{*}{ Scaling } & Before & 25 & 3 & 4 & 3.64 & 0.49 & 4 & 3 & 4 & 4 \\
\hline & After & 25 & 0 & 2 & 0.88 & 0.67 & 1 & 0 & 1 & 1 \\
\hline \multirow{2}{*}{ Total } & Before & 25 & 25 & 32 & 28.24 & 2.03 & 28 & 26.5 & 30 & 28 \\
\hline & After & 25 & 2 & 13 & 8.44 & 2.50 & 9 & 7 & 10 & 9 \\
\hline
\end{tabular}

The descriptive statistics of scores all the parameters of Lakshanas of Ekakusta in Group A are found to be in minimum and maximum value, mean with standard deviation and mode, median with first quartile (Q1) and third quartile (Q3).

Table 2: Descriptive statistics of Lakshanas of Ekakusta in Group B

\begin{tabular}{|l|c|c|c|c|c|c|c|c|c|c|}
\hline $\begin{array}{l}\text { Lakshanas of } \\
\text { Ekakusta - Group - B }\end{array}$ & At & N & Min & Max & Mean & SD & Median & Q1 & Q3 & Mode \\
\hline \multirow{2}{*}{ Aswedana } & Before & 25 & 2 & 4 & 3.56 & 0.65 & 4 & 3 & 4 & 4 \\
\cline { 2 - 12 } & After & 25 & 1 & 3 & 1.84 & 0.75 & 2 & 1 & 2 & 2 \\
\hline \multirow{2}{*}{ Mahavasthu } & Before & 25 & 2 & 4 & 3.36 & 0.64 & 3 & 3 & 4 & 3 \\
\cline { 2 - 13 } & After & 25 & 1 & 3 & 1.48 & 0.59 & 1 & 1 & 2 & 1 \\
\hline \multirow{2}{*}{ Mandala } & Before & 25 & 3 & 4 & 3.6 & 0.5 & 4 & 3 & 4 & 4 \\
\cline { 2 - 12 } & After & 25 & 1 & 4 & 3.28 & 0.84 & 4 & 3 & 4 & 4 \\
\hline Mastyasakalopamam & Before & 25 & 2 & 4 & 3.52 & 0.65 & 4 & 3 & 4 & 4 \\
\hline
\end{tabular}




\begin{tabular}{|l|c|c|c|c|c|c|c|c|c|c|} 
& After & 25 & 0 & 3 & 1.32 & 0.90 & 1 & 1 & 2 & 1 \\
\hline \multirow{3}{*}{ Bahalatha } & Before & 25 & 2 & 4 & 3.08 & 0.64 & 3 & 3 & 4 & 3 \\
\cline { 2 - 12 } & After & 25 & 0 & 3 & 1.36 & 0.76 & 1 & 1 & 2 & 1 \\
\hline \multirow{3}{*}{ Unkshatha } & Before & 25 & 3 & 4 & 3.48 & 0.51 & 3 & 3 & 4 & 3 \\
\cline { 2 - 12 } & After & 25 & 0 & 2 & 0.56 & 0.65 & 0 & 0 & 1 & 0 \\
\hline \multirow{3}{*}{ Kandu } & Before & 25 & 2 & 4 & 2.88 & 0.60 & 3 & 3 & 3 & 3 \\
\cline { 2 - 12 } & After & 25 & 0 & 2 & 0.88 & 0.67 & 1 & 0 & 1 & 1 \\
\hline \multirow{3}{*}{ Scaling } & Before & 25 & 2 & 4 & 3.44 & 0.65 & 4 & 3 & 4 & 4 \\
\cline { 2 - 12 } & After & 25 & 0 & 2 & 0.84 & 0.55 & 1 & 0.5 & 1 & 1 \\
\hline \multirow{2}{*}{ Total } & Before & 25 & 3 & 4 & 3.64 & 0.49 & 4 & 3 & 4 & 4 \\
\cline { 2 - 11 } & After & 25 & 0 & 2 & 1.20 & 0.76 & 1 & 1 & 2 & 1 \\
\hline
\end{tabular}

The descriptive statistics of scores all the parameters of Lakshanas of Ekakusta in Group B are found to be in minimum and maximum value, mean with standard deviation and mode, median with first quartile (Q1) and third quartile (Q3).

The study was clinical trial on 50 patients with Eka kustha. All the patients were randomly assigned to 2 groups. The patients were clinically evaluated and observations were recorded as in the case Performa.

RESULTS: Both the Kashayas are effective in the management of Ekakushtha.

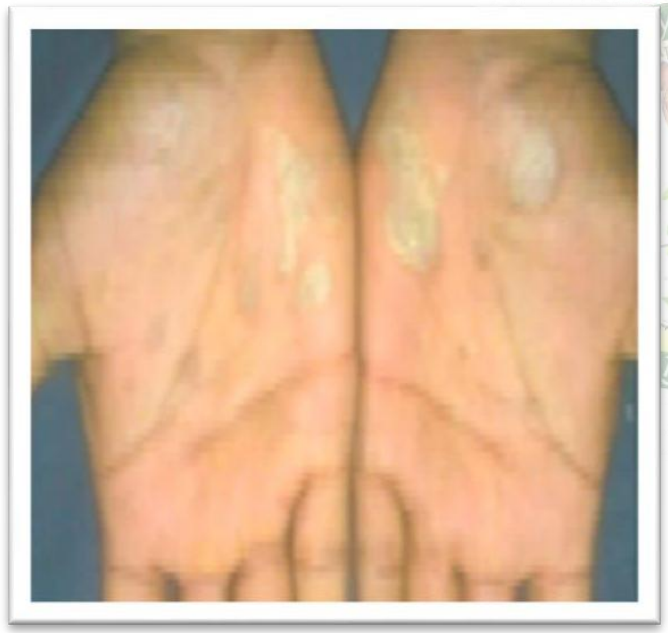

Figure 1: Before Treatment

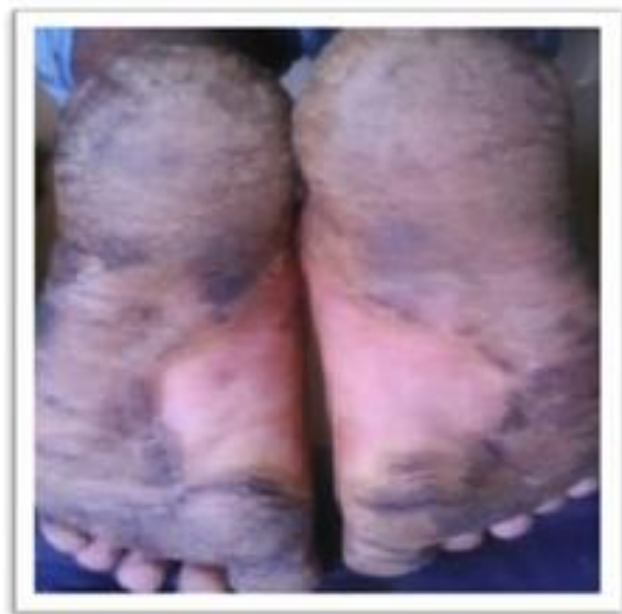

Figure 3: Before Treatment

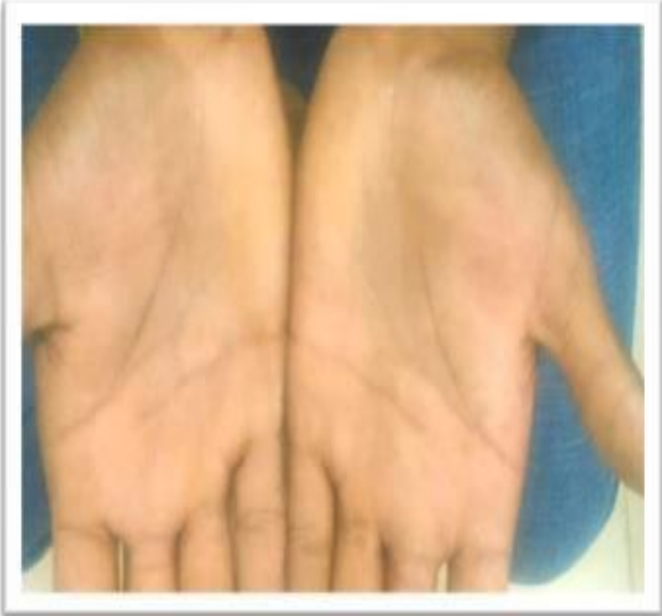

Figure 2: After Treatment

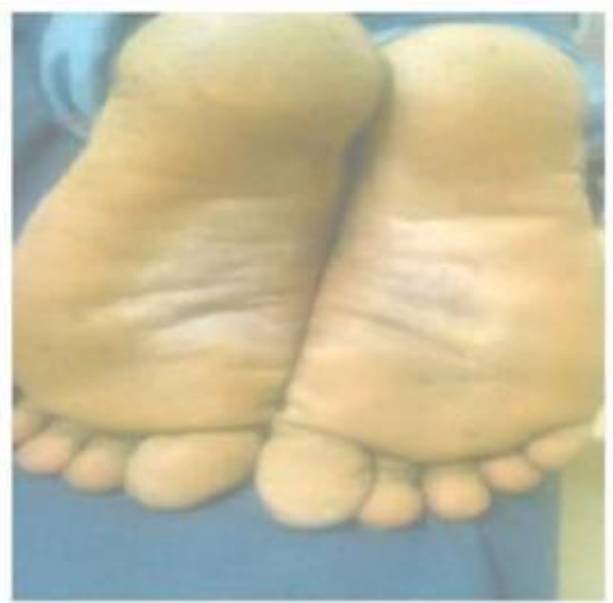

Figure 4: After Treatment 
Int. J. Ayur. Pharma Research, 2021;9(Suppl 1):1-9

Table 3: Agni of patients among groups

\begin{tabular}{|l|c|c|c|c|c|c|}
\hline \multirow{2}{*}{ Agni } & \multicolumn{2}{|c|}{ Group A } & \multicolumn{2}{c|}{ Group B } & \multicolumn{2}{c|}{ Total } \\
\cline { 2 - 7 } & n & \% & N & \% & n & \% \\
\hline Mand & 6 & 24.0 & 8 & 32.0 & 14 & 28.0 \\
\hline Tikshna & 10 & 40.0 & 12 & 48.0 & 22 & 44.0 \\
\hline Vishama & 9 & 36.0 & 5 & 20.0 & 14 & 28.0 \\
\hline Total & 25 & 100.0 & 25 & 100.0 & 50 & 100.0 \\
\hline
\end{tabular}

Assessment of Agni of the patients revealed that maximum number of patients had Tikshna agni and the rest of the patients had Mandagni and Vishamagni.

Table 4: Vyasana of patients among groups

\begin{tabular}{|l|c|c|c|c|c|c|}
\hline \multirow{2}{*}{ Vyasana } & \multicolumn{2}{|c|}{ Group A } & \multicolumn{2}{c|}{ Group B } & \multicolumn{2}{c|}{ Total } \\
\cline { 2 - 7 } & $\mathbf{n}$ & $\mathbf{\%}$ & $\mathbf{N}$ & $\mathbf{\%}$ & $\mathbf{n}$ & $\mathbf{\%}$ \\
\hline Alcohol & 3 & 12.0 & 5 & 20.0 & 8 & 16.0 \\
\hline Smoking & 4 & 16.0 & 2 & 8.0 & 6 & 12.0 \\
\hline Alcohol, Smoking & 2 & 8.0 & 4 & 16.0 & 6 & 12.0 \\
\hline Tea & 13 & 52.0 & 13 & 52.0 & 26 & 52.0 \\
\hline Tobacco & 1 & 4.0 & 0 & 0.0 & 1 & 2.0 \\
\hline Tea, Tobacco & 1 & 4.0 & 0 & 0.0 & 1 & 2.0 \\
\hline No & 1 & 4.0 & 1 & 4.0 & 2 & 4.0 \\
\hline Total & 25 & 100.0 & 25 & 100.0 & 50 & 100.0 \\
\hline
\end{tabular}

Assessment of Vyasana of the patients showed that maximum number of the patients had a habit of consuming tea in both the groups.

Table 5: Comparison of Lakshanas of Ekakusta after the Intervention between the groups

\begin{tabular}{|c|c|c|c|c|c|c|c|}
\hline $\begin{array}{l}\text { Lakshanas of } \\
\text { Ekakusta }\end{array}$ & Group & Median & IQR & $\begin{array}{l}\text { Mean } \\
\text { Rank }\end{array}$ & $\begin{array}{l}\text { Sum of } \\
\text { Ranks }\end{array}$ & $\begin{array}{c}\text { Mann- } \\
\text { Whitney U }\end{array}$ & p-value \\
\hline \multirow{2}{*}{ Aswedana } & A & 1 & $0-1$ & 17.84 & 446 & \multirow{2}{*}{121} & \multirow{2}{*}{0.000069} \\
\hline & B & 2 & $1-2$ & 33.16 & 829 & & \\
\hline \multirow{2}{*}{ Mahavasthu } & $\mathrm{A}$ & 1 & $1-1$ & 21.5 & 537.5 & \multirow{2}{*}{212.5} & \multirow{2}{*}{0.026212} \\
\hline & $\mathrm{B}$ & 1 & $1-2$ & 29.5 & 737.5 & & \\
\hline \multirow{2}{*}{ Mandala } & A & 1 & $0-2$ & 13.84 & 346 & \multirow{2}{*}{21} & \multirow{2}{*}{0.000000} \\
\hline & $\mathrm{B}$ & 3 & $3-5$ & 37.16 & 929 & & \\
\hline \multirow{2}{*}{ Mastyasakalopamam } & A & 1 & $0.5-1.5$ & 23.42 & 585.5 & \multirow{2}{*}{260.5} & \multirow{2}{*}{0.275537} \\
\hline & $\mathrm{B}$ & 1 & $1-2$ & 27.58 & 689.5 & & \\
\hline \multirow{2}{*}{ Bahalatha } & $\mathrm{A}$ & 1 & $1-2$ & 24.94 & 623.5 & \multirow{2}{*}{298.5} & \multirow{2}{*}{0.765250} \\
\hline & $\mathrm{B}$ & 1 & $1-2$ & 26.06 & 651.5 & & \\
\hline \multirow{2}{*}{ Rukshatha } & A & 1 & $0-1$ & 25.96 & 649 & \multirow{2}{*}{301} & \multirow{2}{*}{0.803084} \\
\hline & B & 0 & $0-1$ & 25.04 & 626 & & \\
\hline \multirow{2}{*}{ Unnathi } & A & 1 & $1-1$ & 25.62 & 640.5 & \multirow{2}{*}{309.5} & \multirow{2}{*}{0.945407} \\
\hline & B & 1 & $0-1$ & 25.38 & 634.5 & & \\
\hline \multirow{2}{*}{ Kandu } & $\mathrm{A}$ & 1 & $0-1$ & 24.96 & 624 & \multirow{2}{*}{299} & \multirow{2}{*}{0.760595} \\
\hline & $\mathrm{B}$ & 1 & $0.5-1$ & 26.04 & 651 & & \\
\hline \multirow{2}{*}{ Scaling } & $\mathrm{A}$ & 1 & $0-1$ & 22.5 & 562.5 & \multirow{2}{*}{237.5} & \multirow{2}{*}{0.115320} \\
\hline & $\mathrm{B}$ & 1 & $1-2$ & 28.5 & 712.5 & & \\
\hline \multirow{2}{*}{ Total } & A & 9 & $7-10$ & 15.96 & 399 & \multirow{2}{*}{74} & \multirow{2}{*}{0.000003} \\
\hline & B & 13 & $11-15$ & 35.04 & 876 & & \\
\hline
\end{tabular}

The Aswedana in Group A is Median=1 with $\mathrm{IQR}=0-1$ and Median=2 with IQR=1-2 in Group B; And Mean Rank of Group A is 17.84 lowest mean rank; with
Mann-Whitney U=121 with p-value $=0.000069<0.05$, therefore there is a statistically significance difference in Aswedana among the groups. 
The Mahavasthu in Group A is Median=1 with $\mathrm{IQR}=1-1$ and Median=1 with IQR=1-2 in Group B; And Mean Rank of Group A is 21.5 lowest mean rank; with Mann-Whitney $U=212.5$ with p-value $=0.026212<0.05$, therefore there is a statistically significance difference in Mahavasthu among the groups.

The Mandala in Group A is Median=1 with $\mathrm{IQR}=0-2$ and Median=3 with IQR=3-5 in Group B; And Mean Rank of Group A is 13.84 lowest mean rank; with Mann-Whitney $\quad U=21$ with $p$-value $=0.000<0.05$, therefore there is a statistically significance difference in Mandala among the groups.

The Mastyasakalopamam in Group $\mathrm{A}$ is Median=1 with IQR=0.5-1.5 and Median=1 with IQR=12 in Group B; And Mean Rank of Group A is 23.42 lowest mean rank; with Mann-Whitney $\mathrm{U}=260.5$ with p-value $=0.275537>0.05$, therefore there is no statistical significance difference in Mastyasakalopamam among the groups.

The Bahalatha in both Group A and B is Median=1 with IQR=1-2; And Mean Rank of Group A is 24.94 lowest mean rank; with Mann-Whitney $U=298.5$ with $\mathrm{p}$-value $=0.765250>0.05$, therefore there is no statistical significance difference in Bahalatha among the groups.

The Rukshatha in Group A is Median=1 with $\mathrm{IQR}=0-1$ and Median=0 with IQR=0-1in Group B; And Mean Rank of Group B is 25.04 lowest mean rank; with Mann-Whitney $\mathrm{U}=301$ with $\mathrm{p}$-value $=0.803084>0.05$, therefore there is no statistical significance difference in Rukshatha among the groups.

The Unnathi in Group A is Median=1 with IQR=1-1 and Median=1 with IQR=0-1in Group B; And Mean Rank of Group B is 25.38 lowest mean rank; with Mann-Whitney $U=309.5$ with p-value $=0.945407>0.05$, therefore there is no statistical significance difference in Unnathi among the groups.

The Kandu in Group A is Median=1 with IQR=01 and Median=1 with IQR=0.5-1in Group B; And Mean Rank of Group A is 24.96 lowest mean rank; with Mann-Whitney $\mathrm{U}=299$ with $\mathrm{p}$-value $=0.760595>0.05$, therefore there is no statistical significance difference in Kandu among the groups.

The Scaling in Group A is Median=1 with $\mathrm{IQR}=0-1$ and Median=1 with IQR=1-2 in Group B; And Mean Rank of Group A is 22.5 lowest mean rank; with Mann-Whitney $U=237.5$ with $p$-value $=0.115320>0.05$, therefore there is no statistical significance difference in Scaling among the groups.

The Total Scoring of Lakshanas of Ekakusta after the Intervention in Group A is Median=9 with IQR=7-10 and Median=13 with IQR=11-15 in Group B; And Mean Rank of Group A is 15.96 lowest mean rank; with Mann-Whitney U=74 with p-value=0.000003 < 0.05 , therefore there is a statistical significance difference in total scoring of Lakshanas of Ekakusta among the groups.

\section{DISCUSSION}

The aim and objectives of the dissertation was "a comparative clinical study to evaluate the efficacy of Guduchyadi kashaya and Rajrukshadipachana kashaya in the management of Eka kushta w.s.r to psoriasis "

In this clinical study, the trial was conducted in a randomly selected 50 patients who were divided into two groups. Group A contains Guduchyadi Kwath and group B contains Rajvrukshadi pachana kashaya. The patients were treated on shaman therapy. After completion of study following observation were seen.

In this study, psoriasis was found in all age group from 16 to 60 years. It indicates widespread appearance of Psoriasis. But maximum number of patient were found in age group between 31-40 yrs. Psoriasis is a disease that manifests in all the age groups, the first peak occurrence of plaque psoriasis is in people age 16-22years. The second peak is in people aged 57-60 years. Onset before age 40 usually indicates a greater genetic susceptibility. Due to more stressful life and life style and dietary disturbance in young age incidence is found more in age group of 3140years.

In Gender wise distribution, $60 \%$ patients were male. In other studies of India also, the percentage of male was predominant. The reason behind male predominance could not be ascertained.

Maximum i.e. $82 \%$ of the patient were married, followed by $18 \%$ of patient were unmarried.

Stress is considered as triggering factor in psoriasis. When people faces a situation with great emotions, fear, anger, surprise they are induced into the "fight or flight" sensation taking place in the sympathetic autonomic nervous system. More chances are there for a individual with genetic predisposition to psoriasis to experience a flare up soon after a stressful time or situation in their life. Due to adrenal fatigue one may become sick due to a weakened immune system from the overload of cortisol response.

In this study maximum no of patient reported were labourers i.e., 30\% and Farmers i.e. 14\%. Patient reported with this profession have stress factor which may be aggravating psoriasis.

Ahara play an important role in disease aggravation, most of the patient were having mix diet i.e. veg + non vegetarian $54 \%$. Most of patient in this group consume non vegetarian diet 2 to 3 times in a week. $3.33 \%$ of the patient was having positive family history; this positive history was found from maternal side. Most of the patients were having Vatapittaj prakruti might be due Eka Kustha is predominant in Vata Kaphaj Dosha. The observation of the patient in Agni Pariksana most of were Tikshna Agni. 
Maximum number of patient was having Krura kostha, in this most of the patients were dealing complaint of constipation for that they used to take laxatives on regular basis and were get addicted to that.

When patient have an itching sensation, the temptation is to scratch. Scratching can increase inflammation and can make itching even worse. Which further leads to a vicious pattern known as the itchscratch cycle.

It is observed in most of the patient, stress is another itching trigger. When patient is under stress, they likely to have psoriasis flare, which can set off another bout of itching. Weather condition can also influence itching. In winter and summer most of the patient with psoriasis reported their itching symptoms get aggravated.

According to the habit, the role of alcohol consumption and smoking in the patient was more in working people than farmers and business man. Most of the patient was educated but there is no relation between disease and education. According to duration most of the patient was suffering from more than $1 \mathrm{yr}$.

According to modern science it is chronic disease, it indicate the chronic nature of psoriasis. Eka Kustha (psoriasis) Vatakapha predominant disease, Kapha Dosha may be responsible for chronicity. The life of the patient got disturbed when they suffered repeated episodes of the psoriasis. The diseased person get relief into sign and symptoms after long treatment but the duration in which the disease will relapse it has no specific duration. The next episode of the disease is worse than the previous.

The patient was observing the relief in the sign and symptoms in the March i.e. March phenomenon of disease. But the aggravating season for most of the patient was in winter followed by summer, it is due to aggravation of Dosha. In winter there is dominancy of Kapha Dosha and Vata which causes increase in VataKapha pradhana Vyadhi like Psoriasis.

Most of the patients were of plaque type of Psoriasis, it indicate that plaque is common type of psoriasis. Candle grease sign was present in the entire patient. In the history of onset it was gradual onset. Most of the patient complained that psoriasis starts from scalp region with itching and scaling, after that it spread all over the body. From this observation it is found that the common area of psoriasis is scalp, knee and extensor surface arm, shoulder, forearm, elbow and leg.

\section{Discussion on Subjective and Objective Criteria}

Aswedanam - There was a Sweda Pravrutti before and after the treatment in group A. Vata Dosha causes Sankocha (Vasoconstriction) and cause obstruction in Swedavaha Srotas which lead to Aswedanam. Vitiated
Kapha Dosha leads to Sanga i.e., obstruction of Swedavaha Srotas and cause Aswedanam symptom.

Mastyashakalopam - There is statistically significant difference in the values before and after treatment in group A and B. Hence Guduchyadi kashaya is effective in the management.

Mahavastu - There is statistically significant difference in the values before and after treatment in group A and B. Hence Rajvrukshadi Pachana kashaya is effective in the management.

PASI Score- Psoriasis Area Severity Index. It is a quantitative score used for measuring the severity of psoriatic lesion based on area covered and appearance of plaque. There is statistically significant difference in the values before and after treatment in group A and B. Hence both the Kashayas are effective in the management.

All the Kustha Roga have predominance of Tridosaja, EkaKustha have mainly the predominance of Vata-Kapha Dosha. The vitiated Vata and Kapha Dosha adversely affect the Jala Mahabhuta component, which affects skin region. This causes the affected skin to appear whitish or coppery color, scaly. In Samprapti of Eka Kustha, the vitiated Vata Dosha dries the water element of skin and promotes abnormally rapid proliferation of skin.

The contents of Guduchyadi Kwatha and Rajvrukshadi Pachana Kashaya have properties like Tridoshashamak, Kusthaghana, Ushna Veerya, Katu, Tikta, Kashaya rasa. Guduchi and Daruharidra acts on Raktavaha Strotas, Triphala is Uttam Agnivardhaka and Pachan Dravya this quality of these drugs work for Samprapti Bhanga of Ekakustha.

Krushnaaruna Varna of skin mainly in Eka Kustha is due to Vitiation of Vata Dosha followed by Kapha and Pitta. Guducyadi Kwatha and Rajvrukshadi Pachana Kashaya contains main drug as Guduchi, which is having Tikta, Madhura vipak and Ushna veerya, which acts on Vata Dosha as well as on Kapha Dosha also. Other drugs also act as Vata Kapha shamaka. Rakta is one of the Dushya in Kustha roga. Mula sthana of Raktavahastrotas is Yakrit. Guduchi acts on Yakrita and also does the shaman of Rakta Dosha, it also acts as Raktaprasadana, and the other drugs like Amalaki, Bibitaki, Haritaki, Suddha Guggulu Daruharidra acts to normalize the skin colour by acting on bhrajaka Pitta, which is also responsible of Krushnaaruna Varna.

Mastyashakalopam symptom is mainly due to vitiation of Vata and Kapha in Ekakustha. Vitiated Vata in Twacha produces more dead cell (scaling) within 2 14 days by increasing frequent cell division. Here the Vata Dosha is suppressed by the properties of Guduchi and other drugs as discussed above. 
Snigdhata and Slakshnata of vitiated Kapha produce smooth and silvery skin but due to vitiated Vayu lesion are not $100 \%$ smooth and Slakshna, Vayu produce a little roughness on lesion which gives appearance of Mastyashakalopam. Guduchi and other drugs in Kwatha acts on Rasavaha strotas, Rukshata is one of the Lakshana of Rasadhatu Kshaya. Rukshata is also Guna of Vata which is responsible for roughness of skin. All the contents of Guduchyadi Kwatha and Rajvrukshadi pachana kashaya have Tridosha shamana properties which reduced the symptom Mastyashakalopam. Hence due to above properties of Guduchyadi Kwatha was found significant in Krushna aruna varna and Mastyashakalopam.

Aswedanama is caused due to vitiation of Vata and Kapha Dosha. When Vata get vitiated it causes Sankocha i.e., Vasocontriction which leads to obstruction of Swedavaha Strotas. Kapha cause obstruction (Sanga) of Sweda.

The skin is a potential target for oxidative injury as it is continuously exposed to ultra violet radiation and other environmental stresses generating reactive oxygen species (ROS). Inadequate antioxidant protection or excess ROS production creates a condition known as oxidative stress, contributing to the progression of cutaneous disease disorder.

Antioxidant protects epidermis from the events that contribute to epidermal toxicity and disease. Deficiencies in any of the antioxidant defense system can cause a reduction in the total antioxidant status (TAS). The drugs like Guduchi, Amalaki contain antioxidant properties which prevent oxidative injury.

\section{CONCLUSION}

The study was conducted to evaluate the efficacy of Guduchyadi Kwatha and of Rajvrukshadi pachana Kashaya in Eka Kustha w.s.r. to Psoriasis.

Following conclusion drawn from the study.

- Guduchyadi Kwatha is found to be more effective in relieving Matsyashakalopamam.

- Rajvrukshadi Pachana Kashaya is found to be more effective in relieving Mahavastu.

- Statistically both the Kashayas are found to be effective in the treatment of Ekakushtha in duration of one month.

- There was significant improvement found in Kandu

\section{Cite this article as:}

Moulika Markonda, Sowmya S.B. A Comparative Clinical Study to Evaluate the Efficacy of Guduchyadi Kashaya and Rajrukshadipachana Kashaya in the Management of Eka Kushta w.s.r to Psoriasis. International Journal of Ayurveda and Pharma Research. 2021;9(Suppl 1):1-9.

https://doi.org/10.47070/ijapr.v9iSuppl1.2090

\footnotetext{
Source of support: Nil, Conflict of interest: None Declared
}

\section{\& Rukshata.}

- Eka Kustha can be correlated with Psoriasis because of similarity in the clinical features.

- Eka Kustha was found in all age group from 16yrs to $60 y$ rs and frequent in males than females.

- Common area involved was scalp, knee and extensor surface arm, shoulder, forearm, elbow and leg.

\section{REFERENCES}

1. K.Sembulingam and Prema Sembulingam. Essential of Medical physiology, section $5^{\text {th }}$, fourth edition. Jitendar P.vij, Jaypee brothers medical publishers, page no 321.

2. Nicki.R.Colledge, R.Walkar and et al, Davidson's principle and practice of medicine, edition $21^{\text {st }}$ Churchill livinstone, Elsevier, page no 1260

3. Bhishagratatla shri bramhashankar shashtri, Yogratnakar, Uttrardha, Kustha Chiktisa Adhyayay, Chaukhamba prakasan, Varanasi, 1993, 217.

4. Gadhanigraha-kayachikitsakhanda -kusthadhikar$36^{\text {th }}$ chapter-sloka $=61$ page no -771 .

5. Bhishagratatla shri bramhashankar shashtri, Yogratnakar, Uttrardha, Kustha Chiktisa Adhyayay, Chaukhamba prakasan, Varanasi, 1993, 217

6. Vagbhata, Arundatta and Ayurveda Rasayana of Hemadri, Dr.Annamoreswar kunte and krishana Shastri Navre, Astanga Hridayam, Sutra Sthana Krishnadas Acadamy, Varanasi, 2000, 15/17.

7. Kaviraj Ambikadatta shastri, Sushruta Samhita ayurveda tatva Nidana Stana, by Chaukhamba Sanskrit sansthan Varanasi, 2014, 5/27.

8. Kaviraj Ambikadatta shastri, Sushruta Samhita ayurveda tatva Nidana Stana, Chaukhamba Sanskrit sansthan Varanasi, 2014, 5/6.

9. Agnivesha, Charaka Samhita, Ayurved depika, Sutrasthana, Chaukhamba Sanskrit sansthan Varanasi, 2012, Sutrasthana 7/15.

10. K.Sembulingam and Prema Sembulingam. Essential of Medical physiology, section $5^{\text {th }}$, fourth edition. Jitendar P.Vij, Jaypee brothers medical publishers, page no 322.

11. Kaviraj Ambikadatta shastri, Sushruta Samhita ayurveda tatva Nidana Stana, by Chaukhamba Sanskrit sansthan, Varanasi, 2014, 6/27.

12. Agnivesha, Charaka Samhita, Ayurved depika, Sutrasthana, Chaukhamba Sanskrit sansthan Varanasi, 2012, Sutrasthana 8/15.

Disclaimer: IJAPR is solely owned by Mahadev Publications - dedicated to publish quality research, while every effort has been taken to verify the accuracy of the content published in our Journal. IJAPR cannot accept any responsibility or liability for the articles content which are published. The views expressed in articles by our contributing authors are not necessarily those of IJAPR editor or editorial board members.

\section{*Address for correspondence Dr.Moulika Markonda \\ PG Scholar,}

Dept. of Kayachikitsa, Ramakrishna Ayurvedic Medical College Hospital and Research Centre, Bengaluru.

Email:

moulikamarkonda1122@gmail.com 